\title{
Pelatihan Pembuatan Media Pembelajaran Online Bagi Guru di SMPN 1 Batulayar Kabupaten Lombok Barat
}

\author{
Citra Ayu Dewi ${ }^{*}$, Yeti Kurniasih, Yusran Khery, Suryati \\ Universitas Pendidikan Mandalika, Jl. Pemuda No. 59 A, Mataram, 83125 Indonesia \\ Email Korespondensi: ayudewi citra@ikipmataram.ac.id
}

Diterima: April 2020; Revisi: April 2020; Diterbitkan: Mei 2020

\begin{abstract}
Abstrak
Permasalahan dan kendala utama yang dihadapi oleh guru-guru di SMPN 1 Batulayar adalah tidak tersedianya media pembelajaran online, keterbatasan pengetahuan tentang teknologi pembuatan media pembelajaran online serta ditambah lagi dengan metode pengajaran yang masih bertumpu pada komunikasi satu arah yang menyebabkan siswa mudah bosan dan kesulitan memahami isi pengajaran. Kegiatan PKM ini bertujuan untuk meningkatkan kemampuan dan skill para guru di SMPN 1 Batulayar dalam pembuatan media pembelajaran online. PKM dilaksanakan menggunakan metode transfer pengetahuan melalui tahapan-tahapan penyajian materi, praktek dan pendampingan pembuatan media. Berdasarkan hasil analisis dari kegiatan pelatihan dan penugasan yang diberikan saat pelatihan dapat diketahui semua peserta mampu membuat kelas baru, mengupload bahan ajar dalam bentuk file, link dan video, menyimpan bahan ajar dalam layanan Google Drive, mengundang siswa untuk bergabung di kelas. Sedangkan kendala selama pelatihan antara lain belum seluruh siswa memiliki akun Gmail sehingga ini menjadi bagian tugas para guru untuk mengarahkan siswa membuat akun Gmail. Berdasarkan hasil kegiatan yang dilaksanakan dapat disimpulkan bahwa terjadi transfer pengetahuan tentang kemampuan dan skill dalam membuat media pembelajaran online menggunakan aplikasi Google Classroom yang merupakan salah satu aplikasi pendukung pembelajaran daring.
\end{abstract}

Kata Kunci: Media; Pembelajaran online

\section{Training on Making Online Learning Media for Teachers at SMPN 1 Batulayar, West Lombok Regency}

\begin{abstract}
The main problems and obstacles faced by teachers at SMPN 1 Batulayar are the unavailability of online learning media, limited knowledge of online learning media creation technology and added with teaching methods that still rely on one-way communication which causes students to easily get bored and have difficulty understanding teaching content. This PKM activities aimed to improve the abilities and skills of teachers at SMPN 1 Batulayar in making online learning media. PKM is carried out using the knowledge transfer method through the stages of presenting material, practice and assistance in making media. Based on the results of the analysis of the training activities and assignments given during the training, it can be seen that all participants are able to create new classes, upload teaching materials in the form of files, links and videos, save teaching materials in the Google Drive service, invite students to join the class. Meanwhile, the obstacles during the training included that not all students had Gmail accounts, so this was part of the teachers' duties to direct students to create Gmail accounts. Based on the results of the activities carried out, it can be concluded that there is a transfer of knowledge about abilities and skills in making online learning media using the Google Classroom application, which is one of the supporting applications for online learning.
\end{abstract}

Keywords: Media; Online learning

How to Cite: Dewi, C., Kurniasih, Y., Khery, Y., \& Suryati, S. (2020). Pelatihan Pembuatan Media Pembelajaran Online Bagi Guru di SMPN 1 Batulayar Kabupaten Lombok Barat. Lumbung Inovasi: Jurnal Pengabdian kepada Masyarakat, 5(1), 16-22. doi:https://doi.org/10.36312/linov.v5i1.460 


\section{PENDAHULUAN}

Perangkat lunak memiliki pengaruh langsung maupun tidak langsung terhadap pendidikan, seiring dengan kemajuan ilmu pengetahuan dan teknologi. Kemajuan positif ini semakin diperkuat dengan adanya alat-alat bantu yang dapat digunakan untuk membantu komputer berdasarkan perkembangan terkini. Namun pada kenyataannya, penggunaan sarana pembelajaran berbasis komputer di sekolah pedesaan khususnya Kabupaten Lombok Barat masih menjadi hal yang asing karena komputer dianggap sebagai alat untuk menyelesaikan masalah administrasi, seperti menulis soal ujian, rekapitulasi gaji dan kegiatan guru dan karyawan serta kegiatan lainnya yang jauh dari peningkatan standar pendidikan. Hal ini disebabkan terbatasnya keterampilan dan sumber daya bagi guru untuk memprediksi kemajuan ilmiah dan teknis dalam perangkat lunak computer. Hasil penelitian alain juga menemukan masih rendahnya keterampilan TIK guru meskipun berkompeten dalam bidang/mata pelajaran yang diampu (Widaryanto \& Sulfemi, 2019).

Para guru di Kabupaten Lombok Barat lambat laun merasakan keterbatasan informasi dalam aplikasi yang relatif jauh dari faktor perkembangan. Ini adalah masalah serius dalam mengintegrasikan pendidikan antara sekolah di daerah perkotaan dan terpencil. Berdasarkan data Dinas Pendidikan, Olahraga dan Kebudayaan Kabupaten Lombok Barat tahun 2018, jumlah SMA seperti Madrasah Aliyah dan Tsanawiyah sebanyak 100 sekolah dengan 269 kelas. Sekitar $60 \%$ sekolah menengah pertama terletak di pedesaan (Dikbud Lombok Barat, 2018). Kenyataan ini masih banyak sekolah yang belum tersentuh oleh teknologi pembelajaran berbasis komputer.

Permasalahan di atas mendekati permasalahan yang dihadapi di SMPN 1 Batulayar Kabupaten Lombok Barat. Dari hasil observasi dan wawancara langsung dengan Kepala SMPN 1 Batulayar Kabupaten Lombok Barat diketahui bahwa faktor penyebab rendahnya kualitas pembelajaran yakni diduga karena kurangnya kemampuan dalam penggunaan teknologi untuk dijadikan media pembelajaran online oleh guru pada materi pembelajaran tidak optimal. Hal ini diperkuat oleh adanya penerapan model pembelajaran satu arah yakni one-way communication, tidak tersedia media pembelajaran dan kemampuan serta skill dalam membuat media pembelajaran sangat minim. Akibatnya siswa merasa jenuh dan mengalami kesulitan dalam memahami materi yang diajarkan oleh guru sehingga tujuan pembelajaran tidak bisa tercapai sesuai dengan target yang ada pada kurikulum yang berlaku di sekolah tersebut. Maka dari itu, melalui kegiatan PKM ini bertujuan untuk memberikan pemahaman dan skill dalam membuat media pembelajaran yang dapat meningkatkan motivasi dan prestasi belajar siswa sehingga kemampuan para guru dalam pembuatan media pembelajaran menjadi meningkat.

Salah satu media yang cocok dengan karakteristik dari pembelajaran saat ini adalah media pembelajaran online. Media pembelajaran online memungkinkan guru menyampaikan konten secara fleksibel dimanapun dan kapanpun mereka berada. Keunggulan yang ditawarkan media pembelajaran online adalah keserbagunaan dan produktivitas yang lebih tinggi. Kecepatan dan fleksibilitas waktu membuatnya sempurna untuk pembelajaran jarak jauh, siswa dapat belajar di rumah, belajar pada waktu mereka sendiri dan dengan kecepatan mereka sendiri. Meningkatkan efisiensi pembelajaran online, terutama karena rangsangan sensorik yang luas melalui teks, grafik, animasi, dan suara.

Salah satu aplikasi yang dapat membantu para guru mewujudkan interaksi yang efektif antara siswa dan guru adalah google classroom. Google Classroom adalah platform pembelajaran campuran yang didedikasikan untuk setiap cakupan pendidikan, dirancang untuk menemukan solusi atas kesulitan dalam membuat, berbagi, dan mengklasifikasikan setiap tugas tanpa kertas (Kurniawan et al., 2020). Perangkat lunak ini telah diterapkan di Google Apps for Education sejak 12 Agustus 2014. Selain itu, penggunaan media pembelajaran google classroom dapat menjadi sarana komunikasi yang efisien antara guru dan siswa dengan menggunakan fitur komunikasi yang berbeda pada aplikasi. Untuk itu perlu adanya pengetahuan dan keterampilan tentang bagaimana komunikasi efektif dapat dilakukan melalui media pembelajaran online (Google Classroom), sehingga kualitas pengajaran dapat lebih baik (Negara et al., 2020).

Berdasarkan uraian tersebut, pelatihan pengembangan media pembelajaran online bagi guru SMPN 1 Batulayar Kabupaten Lombok Barat diperlukan dalam rangka membekali guru 
dengan keterampilan dan pengetahuan mengenai media pembelajaran online. Adanya komunikasi antar guru SMPN 1 di Batulayar Kabupaten Lombok Barat juga menjadi faktor utama dalam mendukung kelancaran kegiatan pelatihan pembuatan dan penggunaan media karena para guru dapat membuat media pembelajaran online bersama dan memanfaatkan hasil karyanya secara bersama-sama.

Terpilihnya SMPN 1 Batulayar Kabupaten Lombok Barat sebagai tempat kegiatan PKM karena melihat potensi yang dimiliki oleh guru-guru SMPN 1 Batulayar yang telah memenuhi syarat/kriteria dari calon peserta. Tidak ada kesulitan dalam penyediaan peralatan atau bahan yang diperlukan di SMPN 1 Batulayar, karena sebagian besar fasilitas yang dibutuhkan selama operasional pelayanan sudah tersedia, seperti LCD, proyektor dan laboratorium komputer. Semua guru juga memiliki komputer jinjing atau laptop untuk memudahkan kelancaran penyelesaian tugas mereka. Pelatihan ini akan efektif dan guru akan menerapkan hasil pelatihan ini untuk senantiasa meningkatkan kualitas pembelajarannya dengan melakukan inovasi dan peningkatan kualitas sesuai dengan kebutuhan guru yang terampil, sehingga kegiatan pengabdian yang akan dilakukan dapat bermakna untuk transformasi ilmu pengetahuan dan teknologi bagi para guru.

Untuk melaksanakan PKM ini, maka dilakukan secara bermitra (berkolaborasi) antara Tim PKM dari dosen-dosen Program studi Pendidikan Kimia Fakultas Sains Teknologi dan Tehnik Universitas Pendidikan Mandalika Mataram dengan SMPN 1 Batulayar Kabupaten Lombok Barat (Mitra). Peran Mitra dalam hal ini adalah memberikan rekomendasi pinjaman tempat dan fasilitas serta penugasan bagi guru-guru yang layak dan memenuhi syarat untuk diikutsertakan dalam kegiatan PKM dari LPPM Universitas Pendidikan Mandalika Mataram.

Berdasarkan hasil studi pendahuluan yang telah dilakukan, beberapa masalah mitra dapat dicantumkan, yakni: (1) Kurangnya pemahaman guru tentang media online, (2) Guru kurang memiliki keterampilan membuat media pembelajaran online, (3) Kurangnya pemahaman guru dalam penggunaan media pembelajaran online yang menyebabkan siswa mudah bosan, sehingga tujuan pembelajaran tidak tercapai, (4) Sistem yang digunakan guru masih bergantung pada pembelajaran yang lebih menekankan pada konsep teoritis yakni pada level representasi verbal dan matematis. Permasalahan yang tertera merupakan permasalahan yang sangat mendesak untuk dicarikan solusinya, sehingga diharapkan para guru di SMPN 1 Batulayar Kabupaten Lombok Barat memiliki kapasitas dan keterampilan untuk membuat media pembelajaran online setelah kegiatan tersebut dan sekaligus dapat menggunakan media pembelajaran online dalam proses belajar mengajar di kelas dengan harapan siswa lebih mudah memahami pelajaran dan minat belajar siswa meningkat. Kegiatan PKM ini bertujuan untuk meningkatkan kemampuan dan skill para guru di SMPN 1 Batulayar dalam pembuatan media pembelajaran online. Komunikasi intensif antar guru SMPN 1 di Batulayar Kabupaten Lombok Barat juga diharapkan mampu menjadi saran pertukaran ide untuk dapat membuat media pembelajaran online bersama dan memanfaatkan hasil karya secara bersama-sama.

\section{METODE PELAKSANAAN}

Kegiatan PKM ini menggunakan metode transfer pengetahuan dengan tiga kegiatan inti, yaitu penyajian materi, praktek dan pendampingan selama kegiatan pelatiahan pembuatan media pembelajaran online. Penyajian materi berupa pengenalan aplikasi, kemanfaataannya, dan penerapannya dalam pembuatan media pembelajaran online. Praktek dan pendampingan berupa pengoperasionalisasian program dimana para guru mempraktikkan secara langsung pembuatan media pembelajaran sesuai dengan materi ajarnya masingmasing. Adapun tahapan-tahapan dalam kegiatan PKM ini diuraikan lebih lanjut pada bagian ini.

\section{Persiapan}

Pada tahap persiapan ada beberapa hal yang perlu dilakukan, yakni melakukan koordinasi dengan tim internal untuk merencanakan pelaksanaan kegiatan yang dilakukan baik secara konseptual, operasional, pembagian tugas dari masing-masing tim PKM, penentuan dan merekrut peserta pelatihan. Setiap tim PKM bertugas dalam menyusun instrumen kegiatan PKM, seperti daftar hadir peserta, angket kuisioner, konsumsi, publikasi, 
lokasi, dokumentasi, dan sebagainya. Dalam merekrut peserta pelatihan disyaratkan bagi yang mempunyai kemampuan dan keterampilan yang cukup di bidang komputer.

\section{Pelaksanaan Kegiatan Pelatihan}

Pada tahap kegiatan pelatihan para peserta yang hadir adalah para guru yang diutus oleh kepala sekolah SMPN 1 Batulayar Kabupaten Lombok Barat yang telah memenuhi kriteria yang dipersyaratkan. Pelaksanaan kegiatan pelatihan ini mencakup antara lain.

\section{Penyajian Materi}

Penyajian materi terkait tentang "Mengelola kelas Daring Melalui Google Classroom". Narasumber dari kegiatan PKM ini berasal dari tim pengabdi sendiri yang sesuai dengan keahliannya. Kegiatan PKM ini melibatkan mahasiswa sebagai tim teknisi yang membantu terlaksananya kegiatan ini. Selama penyajian materi para peserta diberikan kesempatan untuk bertanya dan berdiskusi langsung dengan pemateri terkait berbagi pengalaman dalam masalah pengelolaan kelas daring menggunakan aplikasi google classroom.

\section{Praktek dan Pendampingan}

Pada tahap ini para peserta diberikan kesempatan untuk mempraktek secara langsung pembuatan media pembelajaran online menggunakan aplikasi google classroom. Selama kegiatan praktek, tim PKM melakukan pendampingan terhadap para peserta dengan membimbing dan mengarahkan dalam pembuatan media.

\section{Evaluasi Kegiatan PKM}

Pada tahap ini, tim PKM melakukan evaluasi terhadap media yang telah dihasilkan oleh para peserta dengan cara memberikan penilaian dan refleksi terhadap penyempurnaan media yang telah dibuat. Hal ini dilakukan karena media yang dihasilkan oleh para peserta akan digunakan sebagai media pembelajaran bagi siswa di kelas. Selain itu, ketua tim PKM menutup kegiatan dengan memberikan saran/masukkan terhadap perbaikan dari media pembelajaran harus disesuaikan dengan mata pelajaran yang diajarkan oleh masing-masing guru.

\section{HASIL DAN PEMBAHASAN}

Pelaksanaan kegiatan pengabdian kepada masyarakat yang dilaksanakan sebagai upaya dalam memberikan solusi terkait media pembelajaran yang akan dipergunakan pada pembelajaran daring selama pandemic covid-19 ini yakni berbentuk kegiatan pelatihan pembuatan media pembelajaran online yang mendukung pembelajaran daring pada dunia pendidikan dengan tahapan antara lain: persiapan, pelatihan dan evaluasi terhadap kegiatan PKM yang telah dilakukan.

\section{Persiapan}

Dalam tahapan persiapan ini meliputi: a. melakukan koordinasi dengan tim internal untuk merancang pelaksanaan kegiatan PKM baik secara konseptual, operasional, serta pembagian tugas oleh masing-masing anggota tim dalam membuat instrumen kegiatan PKM, seperti daftar hadir, angket kuisioner, konsumsi, publikasi, lokasi, dan dokumentasi, b. menentukan dan merekrut para peserta pelatihan sesuai yang dipersyaratkan yakni memiliki kemampuan yang memadai di bidang komputer dan sesuai dengan rekomendasi dari kepala sekolah SMPN 1 Batulayar sebanyak 19 guru dari 30 guru yang ada di SMPN 1 Batulayar.

\section{Pelatihan}

Kegiatan PKM ini dilaksanakan dengan dua pelatihan, dimana pelatihan pertama melalui penyajian materi dengan presentasi, diskusi dan tanya jawab sedangkan pelatihan kedua melalui praktik dan pendampingan secara langsung. Beberapa peserta ada yang belum mengetahui Google Classroom, ada juga yang hanya mendengar dan yang sudah pernah mencoba. Data pengetahuan peserta tentang Google Classroom dijelaskan pada Gambar 1 berikut. 


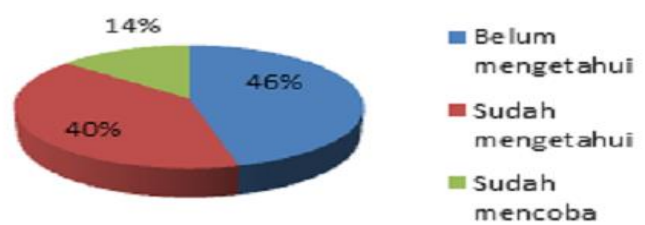

Gambar 1. Distiribusi Pengetahuan Peserta

\section{Penyajian Materi}

Materi yang disajikan oleh narasumber yakni "Mengelola kelas Daring Melalui Google Classroom". Narasumber berasal dari tim pengabdi sendiri disesuaikan dengan bidang keahlian masing-masing. Gambar 2 menunjukkan dokumentasi kegiatan pada saat mempresentasikan materi.

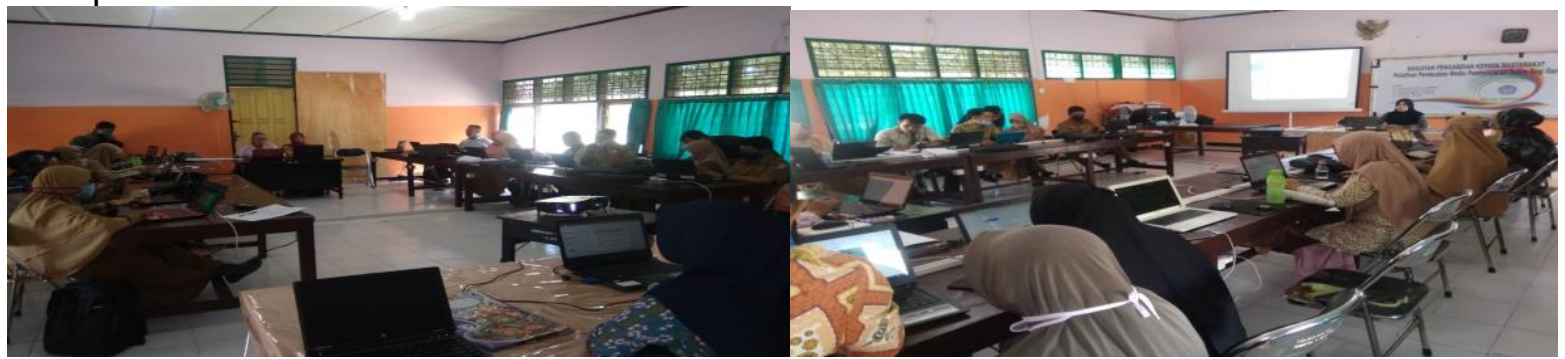

Gambar 2. Kegiatan Penyajian Materi

Pada saat narasumber menyampaikan materi presentasi, Para peserta diberikan kesempatan secara langsung untuk berdiskusi dan bertanya dengan pemateri agar para peserta memahami materi yang disampaikan oleh narasumber dengan topik "Mengelola Kelas daring Melalui Google Classroom". Selama sesi diskusi dan Tanya jawab yang berlangsung para guru sangat antusias dalam menanyakan perihal kelebihan dan kelemahan dalam penggunaan google classroom sebagai media pembelajaran online yang sangat dibutuhkan di masa pandemic covid-19.

\section{Praktik dan Pendampingan Secara Langsung}

Pada sesi praktek dan pendampingan, para peserta dibimbing dan diarahkan oleh tim PKM sampai menghasilkan produk berupa media pembelajaran. Dalam pelatihan ini para peserta ditugaskan untuk membuat satu media pembelajaran online terkait mata pelajaran yang diajarkan oleh masing-masing guru. Untuk dapat membuat media pembelajaran online menggunakan aplikasi Google Classroom peserta diwajibkan memiliki akun Gmail terlebih dahulu yang masih aktif. Hal ini dikarenakan penggunaan Google Classroom tidak memerlukan proses instalansi yang rumit dan jika seorang administrator melakukan setup account google maka user dapat menggunakan layanan Google Classroom dengan akun Gmail masing-masing (Ramadhani et al., 2019). Selanjutnya, Tim PKM melakukan pendampingi kepada masing-masing peserta selama kegiatan praktik pembuatan media pembelajaran online. Selain itu, para peserta dipandu dan dipantau secara langsung serta memberikan bimbingan selama pembuatan media online sampai menghasilkan produk berupa media pembelajaran online (Google Classroom) untuk masing-masing mata pelajaran yang diajarkan sesuai dengan bidang keahlian dari para peserta. Gambar 3 menunjukkan dokumentasi kegiatan pendampingan selama pembuatan median pembelajaran online.

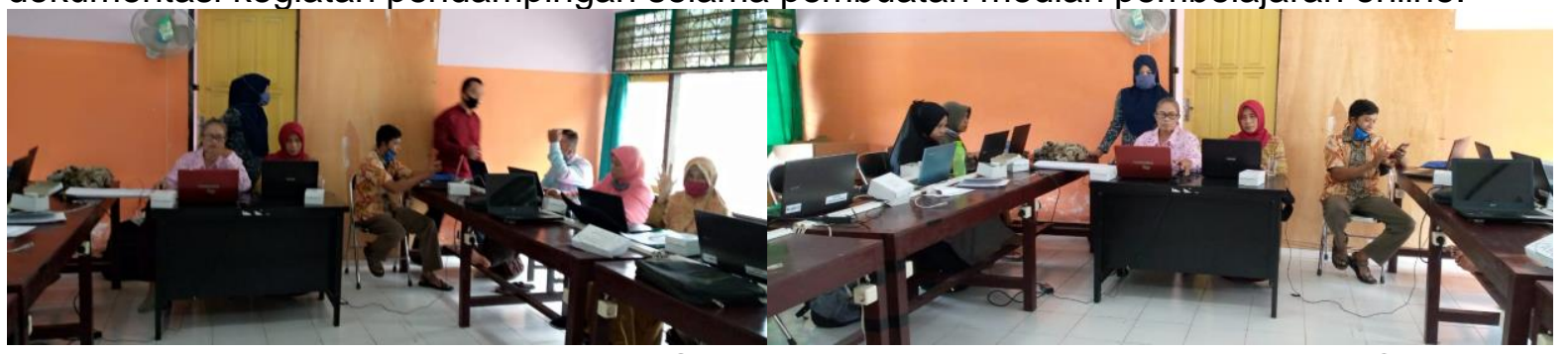

Gambar 3. Praktik dan Pendampingan Selama Pembuatan Media Pembelajaran Online 


\section{Evaluasi terhadap kegiatan PKM yang telah dilakukan}

Pada akhir pelatihan, media yang telah dibuat oleh para guru dikumpulkan dan dinilai oleh tim PKM kemudian disempurnakan oleh tim untuk dikembalikan kepada peserta agar dapat digunakan untuk mengajar. Tindakan ini dilakukan mengingat karya media yang dihasilkan para guru masih perlu penyempurnaan, dan tim PKM berharap agar media pembelajaran betul-betul dapat segera dimanfaatkan untuk mengajar. Selain itu, diakhir kegiatan peserta dan Tim melakukan refleksi hasil pelatihan dan para peserta juga memberikan evaluasi terhadap pelatihan yang telah dilakukan. Peserta mendapatkan koreksi dan evaluasi secara langsung terkait hasil karya mereka. Setelah semua kegiatan yang telah direncanakan terlaksana, ketua tim PKM menutup program dan memberikan pesan kepada segenap peserta pelatihan untuk menerapkan apa yang telah didapatkan untuk memperbaiki media pembelajaran sesuai dengan materi yang diajarkan masing-masing. Selanjutnya, kegiatan tersebut diakhiri dengan foto bersama dengan seluruh peserta kegiatan pelatihan pembuatan media pembelajaran online bagi guru di SMPN 1 Batulayar. Gambar 4 menunjukkan dokumentasi foto bersama dengan para peserta kegiatan PKM.

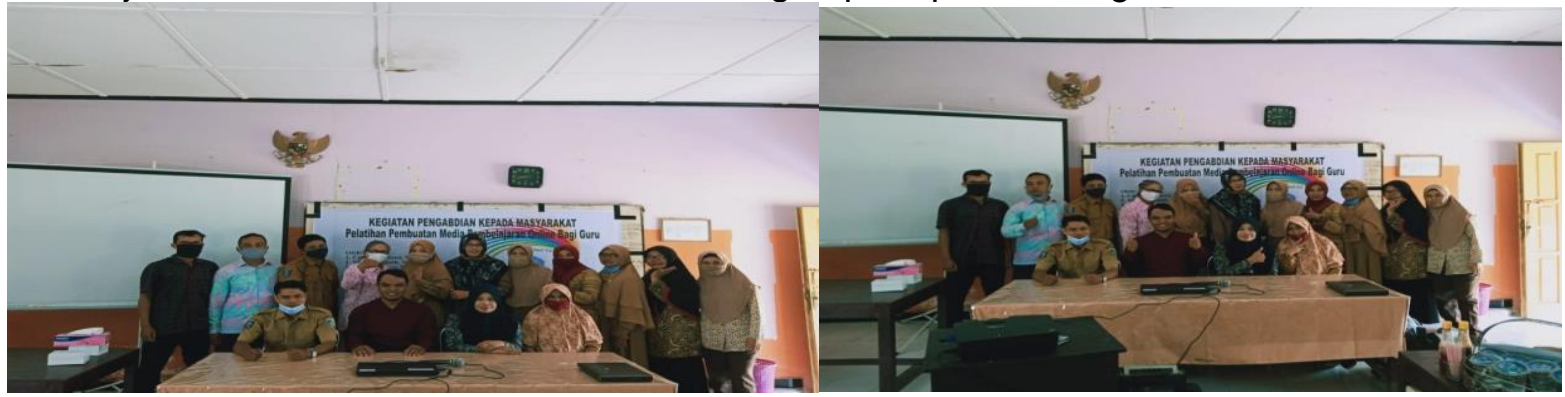

Gambar 4. Foto Bersama Tim PKM Dengan Para Peserta

Berdasarkan hasil pelaksanaan kegiatan PKM yang telah dilakukan menunjukkan bahwa keberhasilan program kegiatan telah tercapai dengan baik dan sesuai dengan harapan. Hal ini terlihat dari antusiasnya para guru selama mengikuti seluruh rangkaian kegiatan pelatihan sampai selesai, baik dalam pemberian materi maupun praktek langsung dalam pembuatan media pembelajaran online. Selain itu, para guru juga memperlihatkan antusiasnya pada saat kegiatan diskusi berlangsung. Para peserta pelatihan merasakan manfaat dari program ini dari sisi pengetahuan maupun teknis sehingga para peserta dapat menyiapkan media pembelajaran online sebagai pendukung pembelajaran daring selama pandemic covid-19. Sejalan dengan hasil kegiatan tersebut, Sari et al (2019) menyatakan, pelatihan guru dalam menggunakan google classroom untuk mengoptimalkan pembelajaran berkontribusi dalam meningkatkan kemampuan guru dalam menggunakan pembelajaran daring. Manfaat penggunaan media pembelajaran juga secara empiris dapat meningkatkan motivasi siswa dan sangat baik digunakan oleh guru (Aris et al., 2019; Hidayat \& Mahanani, 2018). Akbar dan Noviani (2019) menyatakan bahwa guru harus difasilatasi untuk dapat meningkatkan keterampilan dalam penggunaan alat-alat digital karena sangat penting dalam pembelajaran. di samping itu, penguasaan guru tentang TIK juga sangat penting dalam memberikan arahan kepada siswa dalam penggunaan teknologi yang sangat berkembang pesat untuk mereduksi perilaku menyimpang siswa (Kristiawan, 2015; Kristiawan et al., 2017).

\section{KESIMPULAN}

Kegiatan PKM ini secara keseluruhan dapat berjalan dengan lancar dan baik serta respon yang antusias dari peserta pelatihan, dengan jumlah peserta 19 guru SMPN 1 Batulayar. Berdasarkan hasil analisis dari kegiatan pelatihan dan penugasan yang diberikan saat pelatihan dapat diketahui semua peserta mampu membuat kelas baru, mengupload bahan ajar dalam bentuk file, link dan video, menyimpan bahan ajar dalam layanan Google Drive, mengundang siswa untuk bergabung di kelas. Sehingga dengan dilaksanakan kegiatan PKM melalui pelatihan ini terjadi transfer knowledge tentang pemahaman dan kemampuan dalam membuat media pembelajaran online menggunakan aplikasi Google Classroom yang merupakan salah satu aplikasi pendukung pembelajaran daring. 


\section{REKOMENDASI}

Sedangkan kendala selama pelatihan antara lain belum seluruh siswa memiliki akun Gmail sehingga ini menjadi bagian tugas para guru untuk mengarahkan siswanya membuat akun Gmail. Sehingga layanan Google Classroom dapat menjadi salah satu alternatif bagi para guru SMPN 1 Batulayar dalam memilih aplikasi pendukung pembelajaran daring selama pandemic covid-19 ini dan kegiatan pembelajaran dapat berjalan dengan baik.

\section{DAFTAR PUSTAKA}

Akbar, A., \& Noviani, N. (2019). Tantangan Dan Solusi Dalam Perkembangan Teknologi Pendidikan Di Indonesia. Prosiding Seminar Nasional Program Pascasarjana Universitas Pgri Palembang, O(0), 18-25.

Aris, N., Erawaty, N., Massalesse, J., Sirajang, N., Wahda, W., Kasbawati, K., Thamrin, S. A., Sahriman, S., Ramadhan, M. N. B., \& Jaya, A. K. (2019). Peningkatan Kualitas Pembelajaran Matematika Bagi Guru SMA Melalui Media Google Classroom dan Geogebra. JATI EMAS (Jurnal Aplikasi Teknik Dan Pengabdian Masyarakat), 3(2), Article 2. https://doi.org/10.36339/je.v3i2.253

Dikbud Lombok Barat. (2018). Jumlah Sekolah SMA, SMP dan kelas. Kabupaten Lombok Barat. https://lombokbaratkab.go.id/hasil-pembangunan/pendidikan/

Hidayat, T., \& Mahanani, R. S. (2018). Inovasi Teknologi Pengemasan Terasi Udang Puger "Hj. Ariyatun." Prosiding. https://publikasi.polije.ac.id/index.php/prosiding/article/view/1176

Kristiawan, M. (2015). A Model of Educational Character in High School Al-Istiqamah Simpang Empat, West Pasaman, West Sumatera. Research Journal of Education, 1(2), 15-20.

Kristiawan, M., Ahmad, S., Tobari, T., \& Suhono, S. (2017). Desain Pembelajaran SMA Plus Negeri 2 Banyuasin III Berbasis Karakter Di Era Masyarakat Ekonomi ASEAN. Jurnal Iqra': Kajian IImu Pendidikan, 2(2), 403-432. https://doi.org/10.25217/ji.v2i2.178

Kurniawan, B., Purnomo, A., \& Idris. (2020). Pelatihan Penggunaan Aplikasi Google Classroom Sebagai Upaya Peningkatan Pembelajaran Online Bagi Guru Matapelajaran IPS MTs Di Kota Malang. International Journal of Community Service Learning, 4(1), 1. https://doi.org/10.23887/ijcsl.v4i1.22236

Negara, H. R. P., Ibrahim, M., \& Etmy, D. (2020). Pelatihan Pembelajaran Daring (Google Classroom) bagi Guru MTs dan MI Nurul Yaqin Kelanjur. JPMB: Jurnal Pemberdayaan Masyarakat Berkarakter, 3(1), 66-79.

Ramadhani, R., Astuti, E., \& Setiawati, T. (2019). The implementation of Ims-google classroom to improving competence skill of senior high school teachers'in industrial revolution 4.0. Amaliah: Jurnal Pengabdian Kepada Masyarakat, 3(2), 327-335. https://doi.org/10.32696/ajpkm.v3i2.286

Sari, D. P., Sukmawati, R. A., Purba, H. S., Muhammad, D. M., \& Azis, S. H. (2019). Pelatihan Penggunaan Google Classroom untuk Mengoptimalkan Proses Pembelajaran. Bubungan Tinggi: Jurnal Pengabdian Masyarakat, 1(2), 56. https://doi.org/10.20527/btjpm.v1i2.1785

Widaryanto, \& Sulfemi, W. B. (2019). Korelasi penguasaan tik guru dengan kemampuan tik siswa. 14(1), 1-8. https://doi.org/10.31227/osf.io/j23zs 